\title{
THE DIVINE SPIRIT OF BEES. A NOTE ON HONEY AND THE ORIGINS OF YEAST-DRIVEN FERMENTATION
}

\author{
Lorenzo Nigro* - Teresa Rinaldi \\ Sapienza University of Rome
}

One of the earliest domesticated organisms is perhaps the eukaryote microorganism known as Saccharomyces cerevisiae, or more simply "the yeast". Its role in triggering fermentation as a process useful for agricultural products preservation and transformation into food, though known from the Palaeolithic in the ancient Near East, became decisive in the Neolithic Period. The earliest agriculturalists of the Fertile Crescent triggered fermentation with the addition of honey to fruits juices, as attested to in the archaeological record. The yeast, that lives inside the guts of bees and wasps, is apparently responsible for this fermentation process. Honey contains both yeast and sugar that facilitates yeast growth generating fermentation. The productive capability of the bees let these insects to be credited of a divine spirit.

Keywords: bees; honey; Saccharomyces cerevisiae; yeast; Neolithic

Desiccation, salting and fermentation are efficient methods used in food preservation. Since the early days of agriculture during the Neolithic Period, harnessing and exploiting fermentation, thus, enhanced human capacity in production and storage of food. ${ }^{1}$ Transformation of cereals and fruits into edible compounds through fermentation increased their energetic value and prolonged their storage time.

Fermentation happens when a microorganism, through the action of some of its enzymes, transform an organic substance into its simpler components. In particular, fermentation results from the activity of the yeast (Saccharomyces cerevisiae), which rapidly grows when sugars are available, producing alcohol and carbon dioxide as byproduct of its fermentative metabolism. ${ }^{2}$

Human driven fermentation became a routine with the adoption of agriculture during the Neolithic period, by the early communities who first experimented with overproduction and storage of cereals and fruits. ${ }^{3}$ Fermented food is documented in Pre-Pottery Neolithic B (7500-6000 BC) archaeological record from Southern Levant e.g. in Jericho (Tell esSultan), where traces of fermented liquids were found in silos and plastered bins. ${ }^{4}$ The earliest fermented substances in the Neolithic cultures of the Near East were juices of pulped fruits (e.g. jujubes, dates and figs), while the extraction and fermentation of malt of barley and wheat occurred later, after the invention of pottery, from the Pottery Neolithic Period (6000-4500 BC) onwards, leading to brewing. ${ }^{5}$

\footnotetext{
* Department of Oriental Studies, Sapienza University of Rome.

Department of Biology and Biotechnology "Charles Darwin", Sapienza University of Rome; corresponding author: teresa.rinaldi@uniroma1.it.

Marsit - Dequin 2015, 1-2; Fuller - Gonzalez Carretero 2018, 117.

McGovern et al. 2009; Hornsey 2012, 19-54; Dozier 2016.

Bar-Yosef 1995; Colledge 2001; Kuijt - Goring-Morris 2002, 379; Twiss 2007, 30.

Kenyon 1981, pls. 68b, 224, Square FI, Stage XXI, final PPNB.

Weiss - Zohary 2011, 243.
}

ISSN 0393-0300

e-ISSN 2532-5159

Rivista Open Access 
Through observation and experience, the earliest agriculturalists learned how to drive fermentation. They achieved probably unknowingly the most skilful and effective domestication of yeast which eventually was transmitted to the succeeding cultures of the Chalcolithic (4500-3500 BC) and Early Bronze Age (3500-2000 BC). These fermentation skills, first successfully applied to cereals with brewing, were further developed during the Early Bronze Age, when grape started to be systematically cultivated, and when the product of grapes fermentation, wine, achieved an important economic and symbolic value. ${ }^{6}$ The earliest evidence of grape intensive cultivation dates back to the $4^{\text {th }}$ millennium $\mathrm{BC}$, though there is evidence of wine production already in the $6^{\text {th }}$ millennium $\mathrm{BC}^{8}$ and in the Late Chalcolithic period. ${ }^{9}$ However, it is only during the Early Bronze Age, when grape became a distinct production of the Levant, that farmers used to trigger fermentation in grapes' juice by mixing it with fig fruits. This is widely attested to in the archaeological records, with some noticeable examples such as the figs found in Canaanite jars that were part of the funerary objects, for use in the afterlife, of King Scorpion in his tomb of Abydos. ${ }^{10}$

Brewing consisted in smashing and pulping fruits (jujubes, carobs, grapes), adding water and figs keeping the obtained liquid in special vessels (like vats or pithoi) where fermentation could be controlled. Through this process, the earliest agriculturalists activated and managed yeast fermentation. Figs (Ficus carica L.) triggered the fermentation process most likely because these fruits are pollinated by wasps. Recent studies ${ }^{11}$ demonstrated that Saccharomyces cerevisiae is found in the guts of bees and wasps; thus, by pollinating figs and other fruit trees, these insects transmit the yeast to these fruits. ${ }^{12}$ When yeast is in contact with pulped fruits, spontaneous fermentation starts, but only when an appropriate quantity of sugar is available. The quantity of sugar present in fruit juice depends on several factors such as duration of sunlight exposure, appropriate irrigation, pollination and other conditions.

By observing grape or malt juices transformations, the earliest agriculturalists discovered that there was an easier and a more consistent method to trigger and to control fermentation: adding honey in fixed quantities. ${ }^{13}$ Honey in facts contains not only yeasts but also the sugar necessary for the yeast growth and stabilization.

Bee products were harvested since the Paleolithic, ${ }^{14}$ and their important role is testified by an extraordinary rock art paint with a scene of honey hunting (fig. 1). Scientific and archaeological evidence have now confirmed that the exploitation of honeybee was a

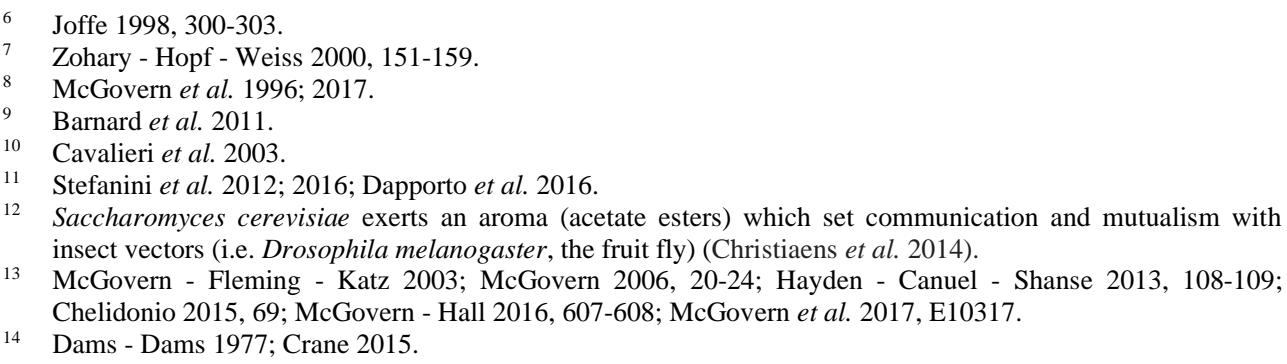


common practice in the communities of the earliest farmers. Bees' products were exploited continuously and extensively by prehistoric farming communities of the Pre-Pottery Neolithic B, e.g. at Jericho, in Palestine, and Çatalhöyük, in central Anatolia, where beeswax residues have been identified in hundreds of pots. ${ }^{15}$ Honeycomb-like pattern decoration (fig. 2) was also depicted on the eastern wall paintings of Çatalhöyük earliest shrine. ${ }^{16}$ The addition of honey to pulped fruit derivatives rich in sugar to trigger a desired fermentation was thus one of the many proficuous uses of honeybee.

Honey-added fermentation became a standard practice since the Neolithic Period, ${ }^{17}$ and bees were considered special creatures, being connected with nature's resurgence in Spring, plants blooming, and producing precious and powerful stuffs: wax, honey, and royal jelly. It is, thus, not surprising that they appear as heraldic animals in the hieroglyphic script next to the name of the pharaohs (fig. 3) and being part of the "throne name" from early Dynastic times in ancient Egypt. ${ }^{18}$ Beehives are depicted in Egyptian paintings and reliefs (fig. 4). ${ }^{19}$ Furthermore, honey is mentioned fifty-five times in the Bible ${ }^{20}$ and in countless administrative, literary, and ritual texts of the ancient Near East, e.g. at Late Bronze Age Ugarit, on the northern Syrian coast.

The addition of honey to fruit juices like grapes wine should no more considered as a way to sweeten them but rather a method to drive fermentation and stabilized the beverage duration. Beekeeping was - in facts - strictly connected with the production of beer and wine, as recent important archaeological discoveries (fig. 5) demonstrated. ${ }^{21}$ In addition to its nutritional and curative benefits, ${ }^{22}$ honey most likely was collected and employed to promote grapes and cereals juices fermentation. For this reason, bees were kept often in temples or in sacred places, such as in Pre-Pottery Neolithic B Jericho, where one of the oldest hives (fig. 6) was found in the courtyard of the one of the earliest shrines so far known. ${ }^{23}$

Bees became essential to the way of life for the early Neolithic farmers and since then they were deemed an extraordinary manifestation of the divine spirit. This may explain why such super-natural origin was considered typical of these insects.

The divine spirit of bees is frequently referred to in literary sources, from Egypt to the Hittite Empire to the Greek and Roman World. ${ }^{24}$

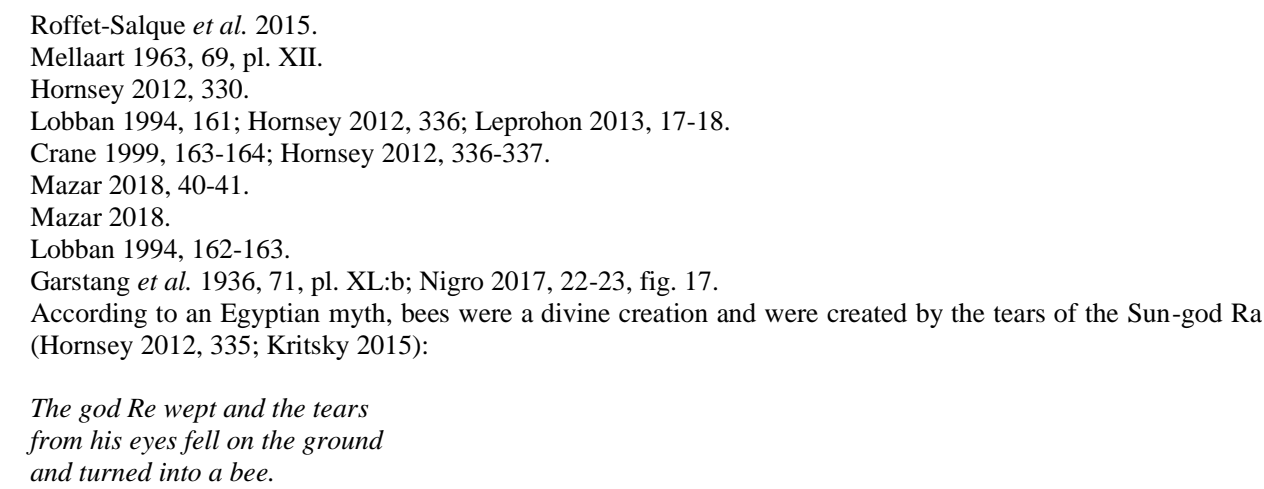




\section{REFERENCES}

BAR-YOSEF, O.

1995 Earliest Food Producers - Pre Pottery Neolithic (8000-5500): T.E. LEVY (ed.), The Archaeology of Society in the Holy Land, Cassell - New York 1995, pp. 190-204.

Barnard, H. - Dooley, A.N. - Areshian, G. - Gasparyan, B. - Faull, K.F.

2011 Chemical evidence for wine production around 4000 BCE in the Late Chalcolithic Near Eastern highlands: Journal of Archaeological Science 38 (2011), pp. 977-984.

CAvalieri, D. - McGovern, P.E. - Hartl, D.L. - Mortimer, R. - Polsinelli, M.

2003 Evidence for S. cerevisiae Fermentation in Ancient Wine: Journal of Molecular Evolution 57 (2003), pp. S226-S232.

CHELIDONIO, G.

2015 Aux origines du vin. Du mythe à la recherche archéologique: Le Globe. Revue genevoise de géographie 155 (2015), pp. 65-86.

Christiaens, J.F. - Franco L.M. - Cools T.L. - De Meester, L. - Michiels, J. - Wenseleers, T. HASSAN, B.A. - YAKSI, E. - VERSTREPEN, K.J.

2014 The fungal aroma gene ATF1 promotes dispersal of yeast cells through insect vectors: Cell Reports 9/2 (2014), pp. 425-432.

The bee made [his honeycomb]

and busied himself with the flowers of every plant;

and so wax was made

and also honey

out of the tears of the god Re

(Papyrus Salt 825, British Museum n. EA10051,4; Free 1982, 93).

When Ra weeps again the water which flows from his eyes upon the ground turns into working bees. They work in flowers and trees of every kind and wax and honey come into being.

(Salt Magical Papyrus, British Museum n. EA10010,8; Ransome 1937, 33).

Bees played an important role also in the Myth depicting the search for the Hittite god of agriculture Telepinu, one of the Old Anatolian myths (Hoffner 1998, 14-20).

Greek mythology often ascribes divine properties to the bees and many stories mention them

(Deliyannis et al. 2018, 56-59).

Finally, a renowned celebration of bees was demonstrated by the Latin poet Vergilius, in the following famous poem

(Georgica, IV, 219-222):

Led by these tokens, and with such traits to guide,

Some say that unto bees a share is given

Of the Divine Intelligence, and to drink

Pure draughts of ether; for God permeates all -

Earth, and wide ocean, and the vault of heaven -

From whom flocks, herds, men, beasts of every kind,

Draw each at birth the fine essential flame;

Yea, and that all things hence to Him return,

Brought back by dissolution, nor can death

Find place: but, each into his starry rank,

Alive they soar, and mount the heights of heaven. (Translation by LN). 
Colledge, $\mathrm{S}$.

2001 Plant exploitation on Epipaleolithic and Early Neolithic sites in the Levant (British CRANE, E. Archaeological Reports. International Series 986), Oxford 2001.

1999 The World History of Beekeeping and Honey Hunting, New York 1999.

2015 The rock-art of honey hunters: Bee World 86/1 (2015), pp. 11-13.

DAMS, L.R.

$1984 \quad$ Les peintures rupestres du Levant espagnol, Paris 1984.

DAMS, M. - DAMS L.R.

1977 Spanish art rock depicting honey gathering during the Mesolithic: Nature 268 (1977), pp 228-230.

Dapporto, L. - Stefanini, I. - Rivero, D. - Polsinelli, M. - Capretti, P. - De Marchi, P. - Viola, R. - TuRILlazZI, S. - CAVALIERI, S.

2016 Social wasp intestines host the local phenotypic variability of Saccharomyces cerevisiae strains: Yeast 33/7 (2016), pp. 277-287.

DeliyAnNis, M. - Tsatsarou, E. - TSAPI, G. - Gousiaris, A.

2018 Kings and queens of the bees in the literary and the scientific tradition: F. HatuINA - G. MAVROFRIDIS - R. Jones (eds.), Beekeeping in the Mediterranean, From Antiquity to the

DOZIER, C present, Nea Moudania 2018, pp. 56-68.

2016 Saccharomyces cerevisiae Fermentation Effects on Pollen: Archaeological Implications: FREE, J.B.

1982 Bees and mankind, London 1982

FUller, D.Q. - GonZALEZ CARRETERO, L.

2018 The Archaeology of Neolithic Cooking Traditions: Archaeobotanical Approaches to Baking, Boiling and Fermenting: Archaeology International 21/1 (2018), pp. 109-121.

GARSTANG, J. - BEN-DOR, I. - FitZGERALD, F.M.

1936 Jericho: City and Necropolis (Report for the Sixth and Concluding Season, 1936): Liverpool Annals of Archaeology and Anthropology 23 (1936), pp. 67-100.

HAYden, B. - CANUEl, N. - Shanse, J.

2013 What Was Brewing in the Natufian? An Archaeological Assessment of Brewing Technology in the Epipaleolithic: Journal of Archaeological Method \& Theory 20 (2013), pp. 102-150.

HOFFNER, H.A.JR.

$1998 \quad$ Hittite Myths, Atlanta 1998.

HORNSEY, I.S.

2012 Alcohol and its Role in the Evolution of Human Society, Cambridge 2012.JoFFE, A.

1998 Alcohol and Social Complexity in Ancient Western Asia: Current Anthropology 39/3 (1998), pp. 297-322.

KENYON, K.M.

1981 Excavations at Jericho, Volume Three. The Architecture and Stratigraphy of the Tell KRITSKY, G. (British School of Archaeology in Jerusalem), London 1981.

2015 The Tears of Re. Beekeeping in Ancient Egypt, Oxford 2015. 
KUIJT, I. - GORING-MORRIS, N.A.

2002 Foraging, farming, and social complexity in the Pre-Pottery Neolithic of the Southern LEPROHON, R.J. Levant: a review and synthesis: Journal of World Prehistory 16/4 (2002), pp. 361-440.

2013 The Great Name: Ancient Egyptian Royal Titulary, Atlanta 2013.

LOBBAN, R.

1994 Bees in Ancient Egypt: Anthrozoös 7/3 (1994), pp. 160-165.

MARSIT, S. - DEQUiN, S.

2015 Diversity and adaptive evolution of Saccharomyces wine yeast: a review: FEMS Yeast MAZAR, A Research 15/7 (2015), pp. 1-12.

2018 The Iron Age apiary at Tel Rehov: F. HATJINA - G. MAVROFRIDIS - R. JonES (eds.), Beekeeping in the Mediterranean, From Antiquity to the present, Nea Moudania 2018, pp. 40-49.

MCGOVERN, P.E.

2006 Ancient Wine: The Search for the Origins of Viniculture, Princeton 2006.

McGovern, P.E. - Fleming, S.J. - KATZ, S.H.

2003 The Origins and Ancient History of Wine: Food and Nutrition in History and Anthropology, New York 2003.

McGovern, P.E. - GLUSKER, D.L. - EXNER, L.J. - Volgt, M.M.

1996 Neolithic resinated wine: Nature 381 (1996), pp. 480-481.

MCGOVERn, P.E. - HALl, G.R.

2016 Charting a Future Course for Organic Residue Analysis in Archaeology: Journal of Archaeological Method and Theory 23 (2016), pp. 592-622.

McGovern, P.E. - Jalabadze, M. - Batiuk, S. - Callahan, M.P. - Smith, K.E. - Hall, G.R. Kvavadze, E. - Maghradze, D. - Rusishvili, N. - Bouby, L. - Failla, O. - Cola, G. - Mariani, L. BoARETTO, E. - BACILIERI, R. - THIS, P. - WALES, N. - LORDKIPANIDZE, D.

2017 Early Neolithic wine of Georgia in the South Caucasus: Proceedings of the National Academy of Sciences 114/48 (2017), pp. E10309-E10318.

McGovern, P.E. - Mirzoian, A. - HaLl, G.R.

2009 Ancient Egyptian Herbal Wine: Proceedings of the National Academy of Sciences 106/18 (2009), pp. 7361-7366

MellaART, J.

1963 Excavations at Çatal Hüyük, 1962: second preliminary report: Anatolian Studies 13

NigRo, L. (1963), pp. 43-103.

2017 Beheaded Ancestors. Of skulls and statues in Pre-Pottery Neolithic Jericho: Scienze RANSOME, H.M. dell'Antichità 23/3 (2017), pp. 3-30.

1937 The Sacred Bee in Ancient Times and Folklore, London 1937. 
Roffet-SAlque, M. - Reger, M. - Evershed, R.P. - Outram, A.K. - CRAmP, L.J.E. - DeCAVAllas, O. - Dunne, J. - Gerbault, P. - Mileto, S. - Mirabaud, S. - PaAkkonen, M. - Smyth, J. - Šoberl, L. Whelton, H.L. - Alday-Ruiz, A. - Asplund, H. - BartKowiak, M. - Bayer-Niemeier, E. Belhouchet, L. - Bernardini, F. - Budja, M. - CoOney, G. - Cubas, M. - DANAhER, E.M. - Diniz, M. - Domboroczki, L. - Fabbri, C. - GonZalez-Urquijo, J.E. - Guilaine, J. - Hachi, S. - Hartwell, B.N. - Hofmann, D. - Hohle, I. - Ibanez, J.J. - Karul, N. - Kherbouche, F. - Kiely, J. - Kotsakis, K. - Lueth, F. - Mallory, J.P. - Manen, C. - MarciniaK, A. - Maurice-Chabard, B. - Mc Gonigle, M.A. - Mulazzani, S. - OzdoĞan, M. - Perić, O.S. - Perić, S.R. - Petrasch, J. - Petrequin, A.-M. Petrequin, P. - Poensgen, U. - Pollard, C.J. - Poplin, F. - Radi, G. - Stadler, P. - Stauble, H. Tasić, N. - Urem-Kotsou, D. - Vuković, J.B. - Walsh, F - Whittle, A. - Wolfram, S. - ZapataPENA, L. - ZOUGHLAMI, J.

2015 Widespread exploitation of the honeybee by early Neolithic farmers: Nature 527 (2015), pp. 226-230.

StefAnini, I. - DAPPORTO, L. - Berná, L. - Polsinelli, M. - TurillazZi, S. - CAVAlieri, D.

2016 Social wasps are a Saccharomyces mating nest: Proceedings of the National Academy of Sciences 113/8 (2016), pp. 2247-2251.

Stefanini, I. - Dapporto, L. - Legras, J.-L. - Calabretta, A. - Di Paola, M. - De Filippo, C. Viola, R. - CAPRetTi, P. - Polsinelli, M. - Turillazzi, S. - CAVAlieri, D.

2012 Role of social wasps in Saccharomyces cerevisiae ecology and evolution: Proceedings of TwISs, K.C. the National Academy of Sciences 109/33 (2012), pp. 13398-13403.

2007 The Neolithic of the Southern Levant: Evolutionary Anthropology 16 (2007), pp. 24-35. WEISS, E. - ZOHARY, D.

2011 The Neolithic Southwest Asian Founder Crops: Their Biology and Archaeobotany: Current Anthropology 52/S4 (2011), pp. 237-254.

ZOHARY, D. - HOPF, M. - WeISS, E.

2000 Domestication of Plants in the Old World, London 2000. 


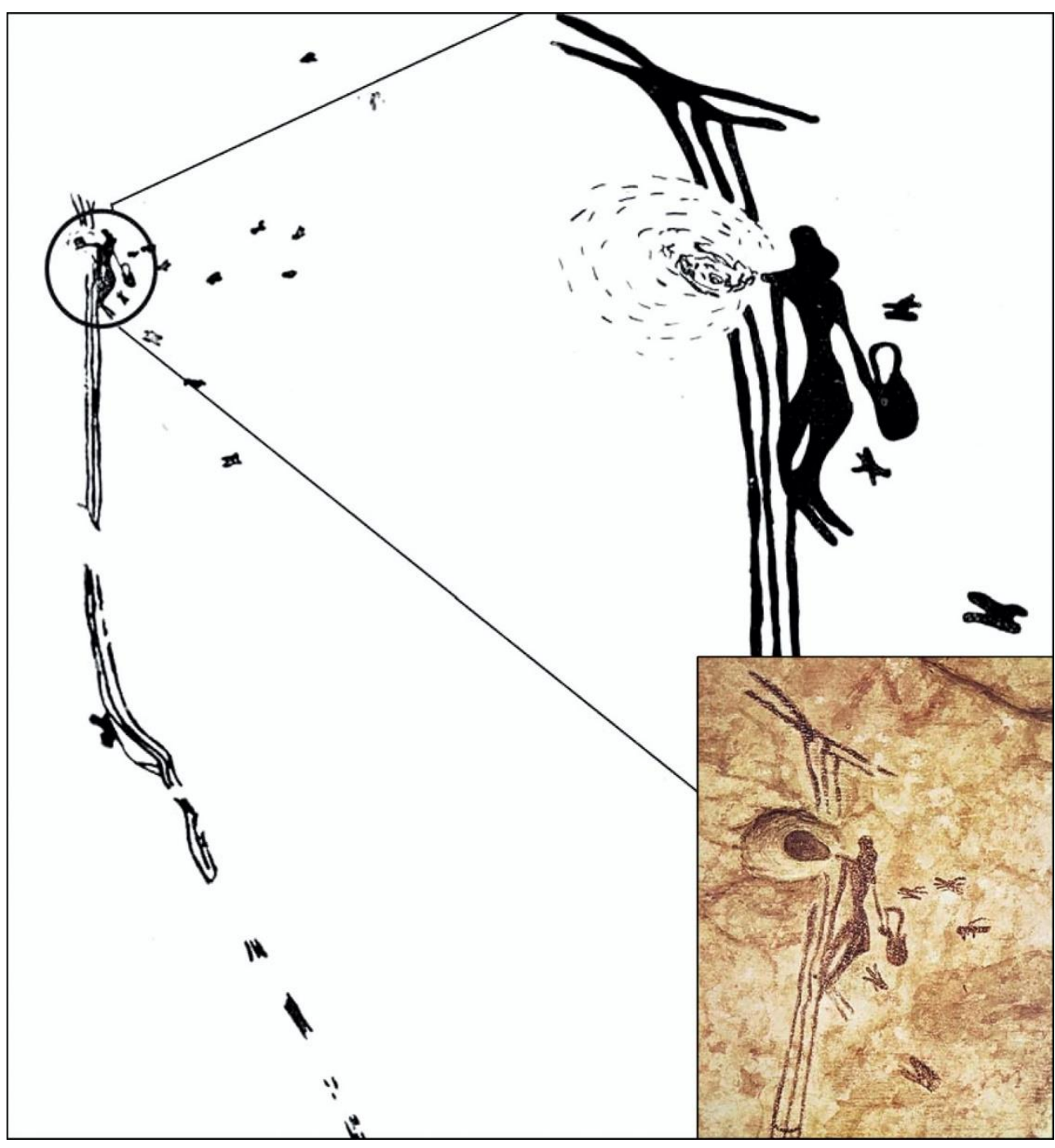

Fig. 1 - Rock painting showing a honey hunter taking honey from a nest and surrounded by angry bees, Cueva de la Araña (8000-6000 BC), Spain (after Dams 1984, 230, fig. 195). 


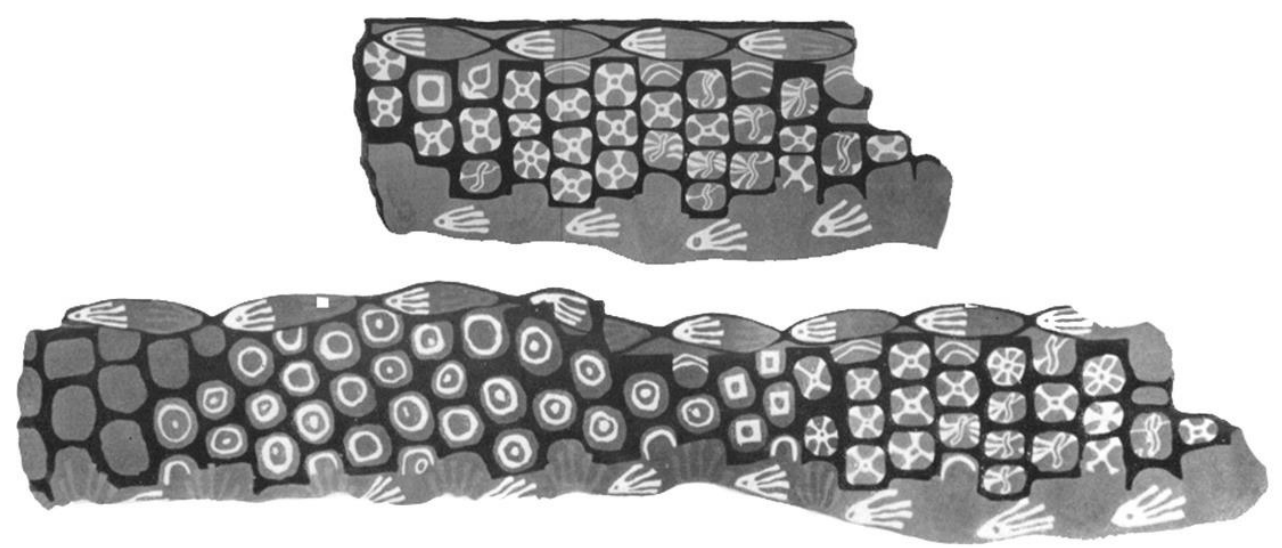

Fig. 2 - Copy of honeycomb and hands pattern depicted on the eastern wall of E VI, 8 shrine ( 6500 BC) at Çatalhöyük (after Mellaart 1963, 69, pl. XII:a, c)
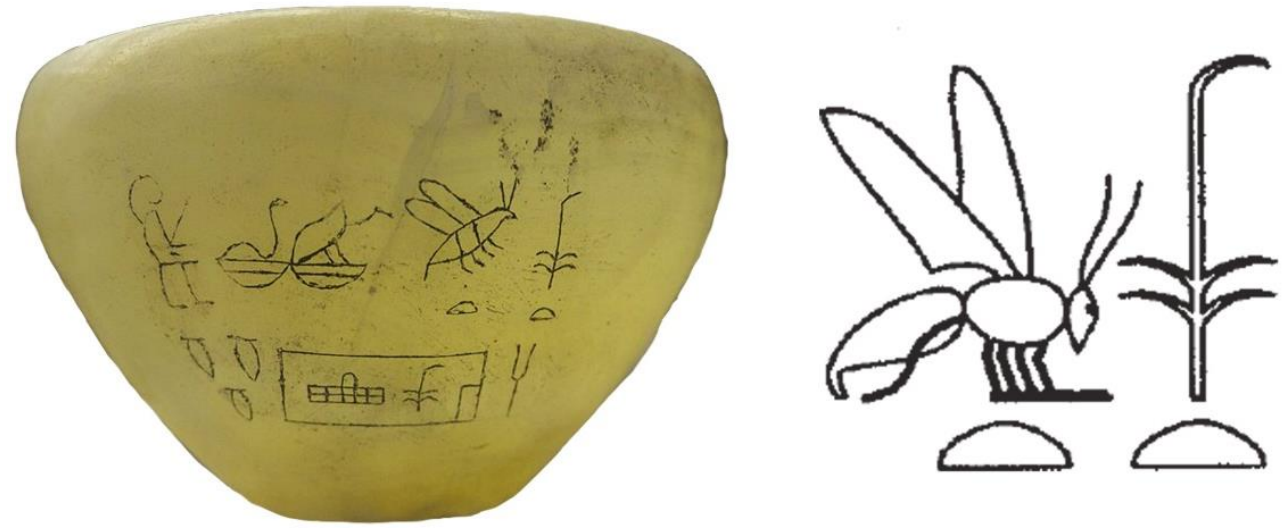

Fig. 3 - The hieroglyph symbol representing the "Throne name", the royal title nsw-bity, which can be translated as "The one of the Sedge and the Bee" and interpreted as the "King of the Upper (the sedge plant) and Lower (the bee) Egypt"; the alabaster vase of Semerkhet attests to the use of the nswt-bity crest already during the I Dynasty. 

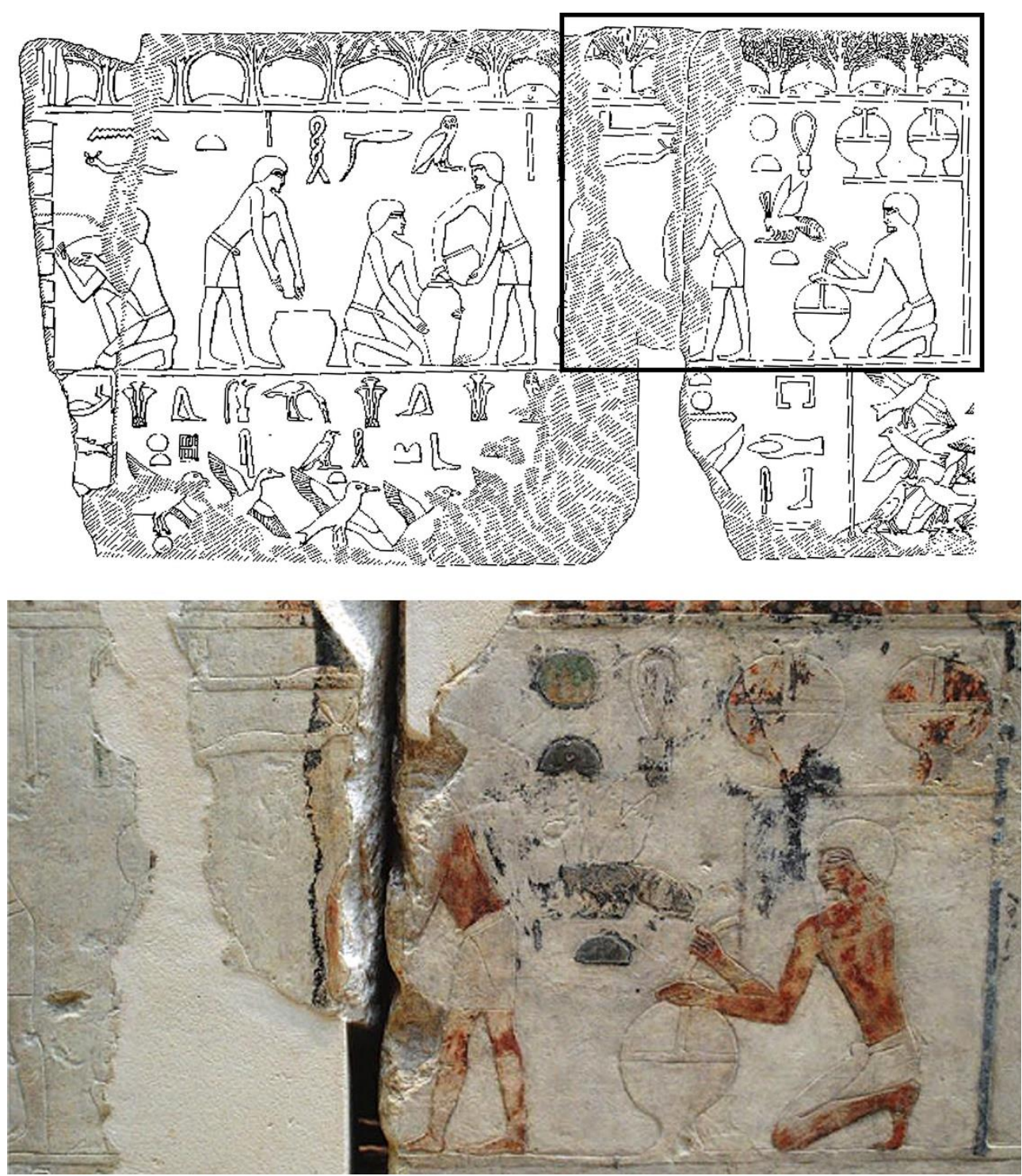

Fig. 4 - Relief from the Temple of the Sun-god Ra of king Ne-user-re at Abu Ghorab, Lower Egypt, V Dynasty, ca. 2400 BC, with the earliest known representation of beekeeping (after Crane 1999, fig. 20:3a; Kritsky 2015, pl. 4). 


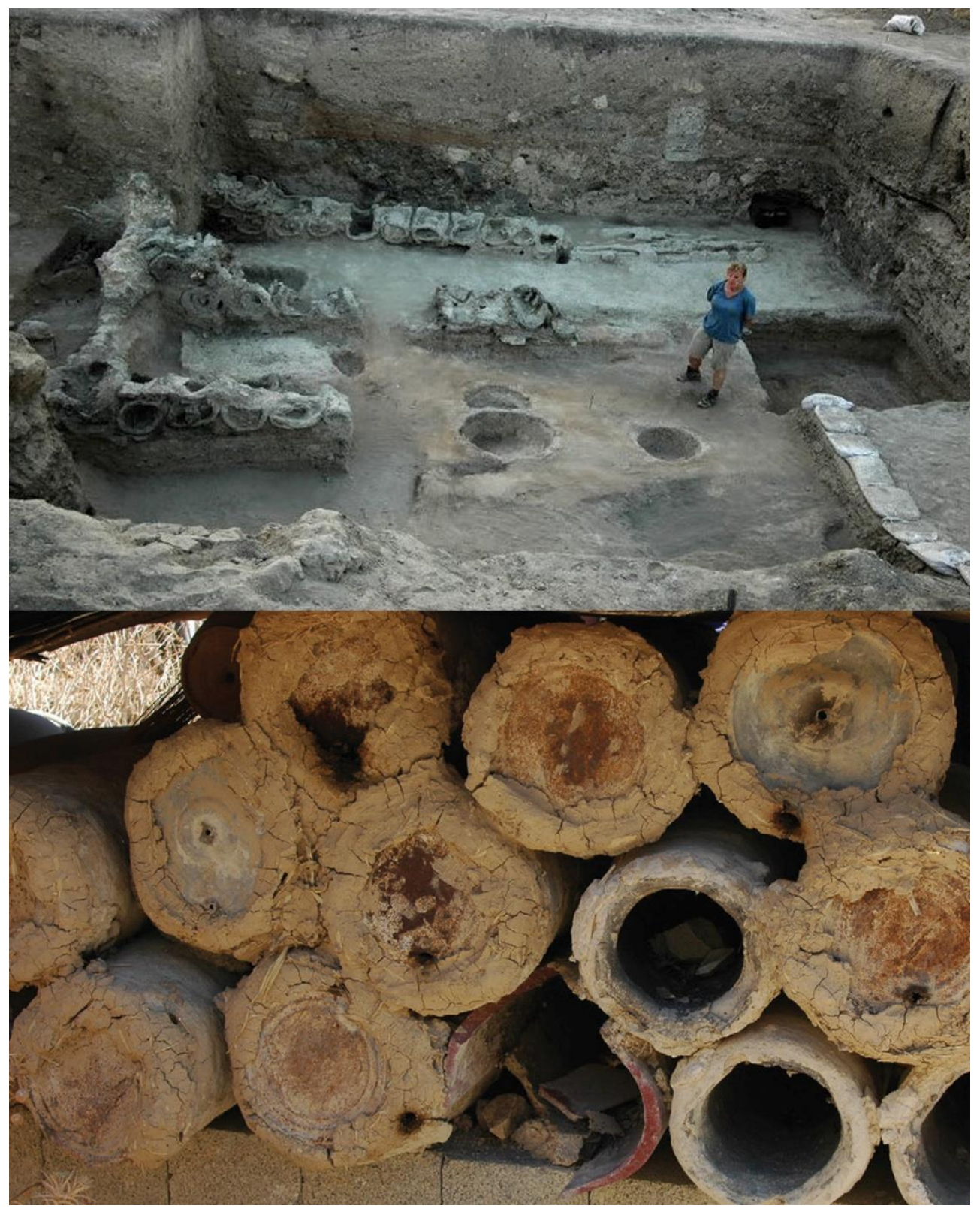

Fig. 5 - The Iron Age (1000-800 BC) apiary found at Tel Rehov/Tell es-Sarem and a modern clay hive in a village of Lower Galilee (after Mazar 2018, figs. 4, 9). 

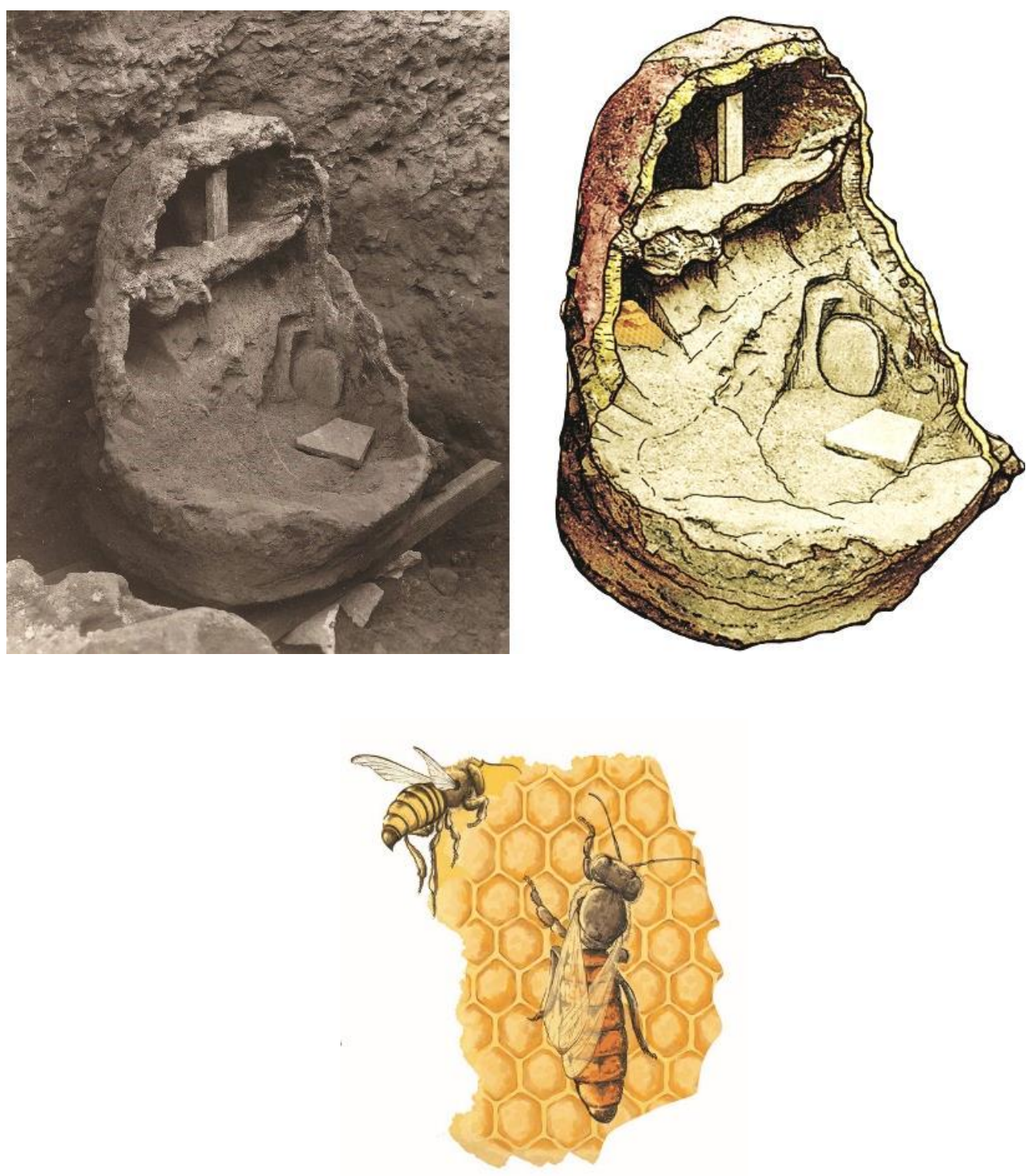

Fig. 6 - Sun-dried clay beehive found in the Level IX (Pre-Pottery Neolithic B, 7500-6000 BC) of the NE Trench at Tell es-Sultan/ancient Jericho (after Garstang et al. 1936, 71, pl. XL:b; drawing by Lorenzo Nigro). 